\title{
Using Engineered microRNAs as Vectors for Animal RNA Interference: Promises and Challenges
}

\author{
Jerry S. Chen' ${ }^{1}$ Robert W. Zeller ${ }^{2}$ \\ ${ }^{1}$ Computational Science Research Center, San Diego State University, San Diego, USA \\ ${ }^{2}$ Department of Biology, San Diego State University, San Diego, USA \\ Email: rzeller@mail.sdsu.edu
}

Received 17 December 2013; revised 4 February 2014; accepted 21 February 2014

Copyright (c) 2014 by authors and Scientific Research Publishing Inc.

This work is licensed under the Creative Commons Attribution International License (CC BY). http://creativecommons.org/licenses/by/4.0/

(c) (i) Open Access

\begin{abstract}
microRNAs are post-transcriptional regulators of gene expression that recruit RNA silencing complexes to target transcripts to prevent translation and promote their degradation. Experimental studies suggest that microRNA binding to target transcripts can result in as much as a $90 \%$ decrease in gene expression. Because of this feature, the microRNA pathway has been utilized as a vehicle for potent RNA interference (RNAi). In recent years, significant advances have been made in engineering artificial microRNA vectors for RNAi in a number of biological systems, with the most progress in plants but also some success in mouse and human cell lines. In this mini-review, we provide a brief discussion of the potential of this technology in comparison with other RNAi strategies, and the current challenges in the design of microRNA-based RNAi vectors, particularly for animal systems.
\end{abstract}

\section{Keywords}

microRNAs; RNA Interference; RNAi

\section{Introduction}

microRNAs (miRNAs) are small RNA molecules that play important developmental roles in both animals and plants, known clinically for their proposed role in preventing cancer formation [1]-[3]. They were first identified in 1993 by the laboratories of Victor Ambros and Gary Ruvkun [4] [5]. Using the nematode worm C. elegans, Ambros and Ruvkun showed that the gene product of a regulatory molecule called lin-4 was necessary for suppressing the activity of a transcription factor (TF) protein called LIN-14 during early larval development. Inte- 
restingly, the product of lin-4 was not a protein as would typically be expected for a molecule with a repressive function, but rather was a tiny RNA molecule less than 70 nucleotides (nt) long. It was then discovered that the sequence of the lin-4 RNA product was highly complementary to a region within the 3' untranslated region (3'UTR) of the LIN-14 messenger RNA (mRNA) transcript. They then suggested that perhaps this RNA-RNA interaction controls the expression of the LIN-14 protein. A few other studies soon followed [6]-[9] but it was not until the complete sequencing of several genomes (including the human genome) at the turn of the century [10]-[13] that microRNA biology blossomed. A flurry of research between 2000 and 2003 demonstrated that these microRNAs were not just chance occurrences, but were in fact abundant in the genome and pervasive throughout the plant and animal kingdom [14]-[36]. This sparked an international scientific endeavor to identify and discover the function of these curious runts of the genome, which continues to this day [3] [37].

\section{Using microRNAs as Vectors for RNA Interference}

\subsection{How microRNAs Are Processed}

microRNAs, like protein-coding genes, are encoded in the genome and transcribed by RNA polymerase II. They can reside as stand-alone genes in independent genetic loci or reside within the introns of host genes. In rare cases, they may even bury themselves within the exons of protein-coding genes [38] [39]. Their processed hairpin transcripts are small, only $~ 70$ base pairs (bp) in length, explaining why they evaded detection in the early days of genome research.

What facilitated the widespread discovery of microRNAs was the resolution of their RNA structure. After the primary miRNA is transcribed from the genome, it folds into a stem-loop structure, which is trimmed into a distinguishable 70 bp hairpin-shaped pre-miRNA molecule by the RNAse III enzyme Drosha [38] [39] (Figure 1). The stems of the pre-miRNA are highly complementary, enabling scientists to find predicted microRNAs by searching for genomic regions with adjacent inverse complementary sequences separated by a small gap that corresponds to the pre-miRNA loop. Since regions of the genome may have consecutive inverse complementary regions by chance, these computational studies generally predict more microRNAs than are found experimentally [18] [40]. Nonetheless, these initial computational studies guided subsequent experimental efforts, which used small-scale methods such as in situ hybridization [41]-[43] and Northern blot [16] [19] [35] as well as largescale methods such as RNA deep sequencing [32] [34] [44] [45] and miRNA microarrays [35] [46]. To date, the current numbers of identified microRNAs range from 200 in C. elegans [47] [48] to over 1000 in humans [48] [49]. Interestingly, whereas the number of protein-coding genes increases at only a modest rate, the number of microRNAs in the genome increases quite significantly in proportion with the complexity of the organism, indicating that the increased complexity of higher organisms may in large part be the result of microRNA expansion [50].

After trimming by Drosha, the 70 nucleotide hairpin pre-miRNA is then shuttled from the nucleus out into the cytoplasm by the nuclear transport receptor Exportin 5, where the loop of the hairpin is then cut by the RNAse III enzyme Dicer [38] [39]. From the resultant 20 - 24 bp RNA duplex, one strand becomes the mature miRNA product. The other strand, known as the miRNA*, is generally thought to be degraded, although recent reports suggest that in a few cases they may also have regulatory capability [51] [52]. The mature miRNA is loaded into a RNA silencing complex containing the RNA-binding protein Argonaute and serves as a guide strand to target and bind partially complementary sites in 3'UTR regions of target mRNAs to regulate their expression [3] [38] [39]. Evidence also exists that Argonaute-complexes frequently bind within coding regions, suggesting that miRNAs may also target these regions as well [44] [45].

\subsection{Engineered microRNA Vectors for RNAi: The Promises}

RNA interference was first achieved by introduction of synthetic long double-stranded RNA into cells or animals, which transiently produce siRNA strands complementary to the desired target gene transcript [53] [54]. RNA interference was first demonstrated in C. elegans [53] and soon after in mammalian cell lines [54] [55]. In more recent years, RNAi has also been used as a therapeutic tool to knock-down the expression of genes implicated in the pathophysiology of many cancers, viral infections, and other diseases [56]-[61].

For more stable and controlled expression of siRNAs in model organisms, vectors have been developed for transcribing short-hairpin RNAs (shRNAs) under the control of RNA polymerase III promoters such as U6 or 


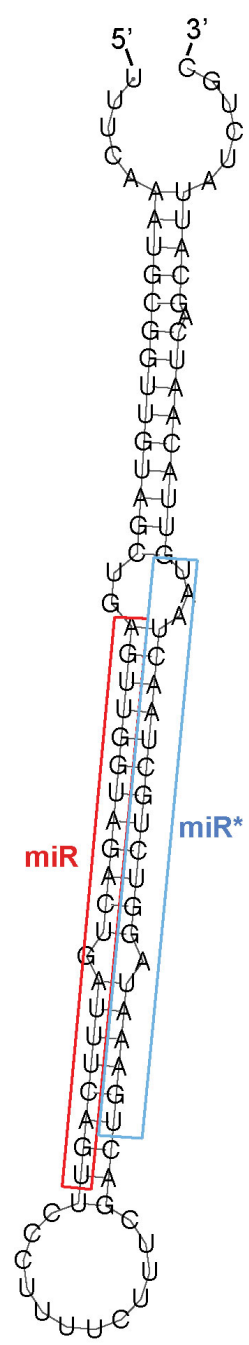

Figure 1. microRNA hairpin structure. Shown here is the pre-miRNA hairpin structure for Ciona miR-155, with the identified mature miR (red) and miRstar (blue) indicated. pre-miRNA hairpins can vary in length from 60 to $100 \mathrm{nt}$, and sometimes have tail flanking regions that are also complementary [36]. The ends of the miR-miR* duplex are cleaved by the RNAse III enzyme Dicer, which leaves overhangs on both ends.

H1 [62] [63], which can either be expressed via extra-chromosomal arrays or directly integrated into the genome using retroviral transduction [62] [64]. Many labs have utilized this technology to create shRNA libraries and stable transgenic lines [62] [65]. However, this strategy does not work in all organisms and in some systems suffers from low efficiency and high off-target effects [66]. Furthermore, since it appears that stable shRNA expression is only achievable using RNA polymerase III promoters, which are constitutively expressed at a certain level in all cell types, the ability to control the timing and level of shRNA expression is currently not possible [62].

An alternative approach is to use microRNA hairpin transcripts as a vector for generating silencing RNAs [62] [67]-[69] (Figure 2). Using this technique, the microRNA hairpin undergoes endogenous processing by the microRNA biogenesis machinery, producing an siRNA-like strand which then targets a desired gene transcript. The hairpin is artificially designed such that the mature and miRNA* strands are replaced by a double-stranded miRNA/siRNA-like duplex, and the entire hairpin cassette is cloned into an appropriate RNA-polymerase II promoter-driven vector (Figure 2). In order to more accurately mimic miRNA duplexes and distinguish themselves from double stranded siRNAs, a bulge is sometimes introduced in the strand replacing the miRNA* so that the opposing strands of the duplex are not perfectly complementary [54]. The result is a vehicle for RNAi that uses the miRNA pathway for processing and can produce tissue-specific miRNA-like small RNAs. Using 


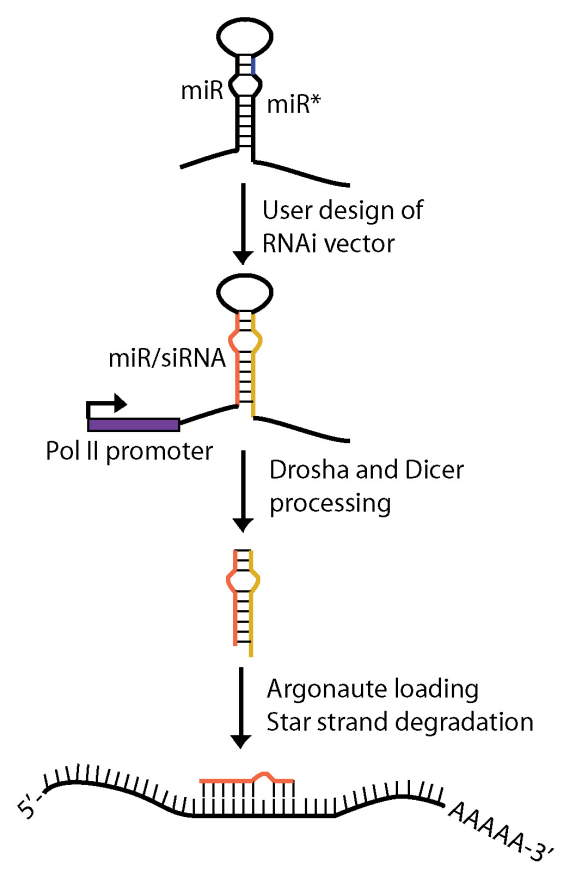

Figure 2. RNA interference using the microRNA pathway. User-designed artifical microRNA hairpins are designed such that the endogenous $\mathrm{miR} / \mathrm{miR}^{*}$ strands are replaced by siRNA-like strands for which the guide miR/siRNA strand (orange) is processed by the endogenous miRNA pathway and targets a desired gene transcript. The RNAi vector is under the control of a selected Pol II promoter, allowing for tissue-specific expression.

transcripts containing miRNA clusters, one can engineer a multi-cassette vector producing multiple miRNA-like small RNAs to target multiple transcripts. Furthermore, since this strategy essentially mimics the processing of endogenous miRNA transcripts, introduction of a miRNA-based vector into cells may circumvent unwanted biological side effects such as type 1 interferon responses that sometimes occur when introducing double-stranded siRNA [68] [70]. RNAi vectors using engineered microRNAs have been successfully developed in a number of systems, most notably in plants [71]-[74], algae [75] [76] and mouse and human cell lines [55] [62]. Collectively, these studies have reported high-specificity of targeting and better knockdown efficiencies than shRNAs. In agreement with previous miRNA studies, miRNA-based RNAi vectors used in human cell lines were shown to result in as much as $\sim 80 \%$ knockdown of gene expression, and the degree of RNAi knockdown is dose-dependent [62] [68]. Notably, it has been shown that efficient RNAi knockdown can result in observable loss-offunction phenotypes [64]. Importantly though, because miRNA target binding in plants requires near-perfect complementarity while in animals requires only partial complementarity, the potential for off-target effects is an important factor to consider when designing and using artificial miRNA RNAi vectors in animal systems. We discuss these challenges below.

\subsection{Engineered microRNA Vectors for RNAi: The Challenges}

One of the primary challenges in using microRNAs for RNA interference in animals is in determining the precise rules for how microRNAs bind to their targets. In plants, microRNAs bind to target sites with near-perfect or perfect complementarity, and therefore design of corresponding RNAi vectors is more straightforward. However, in animals, microRNAs can bind to targets with only partial complementarity, and we still do not know exactly how a microRNA binds to an mRNA target. Through experimental studies over the past decade, it is becoming increasingly clear, however, that there are three large classes of targets based on mRNA binding within the first eight nucleotides of the miRNA, which we refer to as the "seed" region [3]. These are called 8 mer, 7 mer-m8 and 7 mer-A1 seed targets, respectively (Figure 3(A)) [3] [40] [43] [77] [78]. If we merely searched for these kinds of sites within 3'UTR of mRNA transcripts, we would predict that a single microRNA would target on average about 2000 transcripts in human, around 800 per miRNA in simple chordates, and 
A Canonical target sites

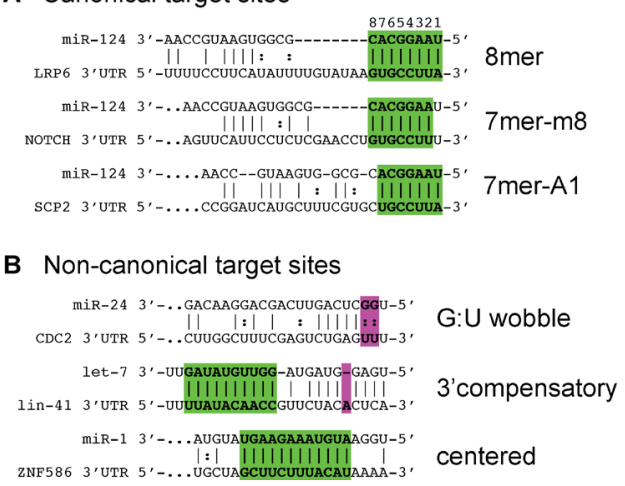

Figure 3. Types of microRNA target sites. (A) There are three types of canonical miRNA target sites: 1) sites perfectly complementary to the entire miRNA seed (8 mer), 2) sites complementary to miRNA nt 2 - 8 (7 mer-m8), and 3) sites complementary to miRNA nt 2 - 7 with an A at position 1 (7 mer-A1) [3]. Shown here are examples of the three canonical target sites complementary to the conserved neuronal miRNA miR-124. (B) There are other types of functional miRNA target sites such as those with a G:U wobble pairing in the seed region, extensive miRNA 3'end compensatory binding, and pairing of $\sim 10$ consecutive nucleotides in the central region of the miRNA.

about 300 - 400 in worms and fruit flies [42] [43] [78]-[80]. Many computational target prediction programs are based on finding seed sites [43] [77] [79]. However, it is generally thought that these are overestimates, and that there are many other biological factors involved such as 3'UTR structure and local thermodynamics which may nullify many of these predicted targets [3] [81]. Although it seems very likely that any mRNA containing a seed site in its 3'UTR is a bona fide target, the lack of precise large-scale protein-based methods hinders our ability to solve this problem definitively. However, from many target expression studies, we do know that the level of downregulation among verified seed targets can vary widely, ranging from as little as $10 \%$ to over $90 \%$ downregulation [43] [77]. To complicate matters, there are several other types of target binding that have been reported to be functional in some, but not all cases. These include mRNA binding with the presence of a single G:U wobble pair within the seed, binding of only miRNA nucleotides $2-7$, binding of the center of the miRNA, and compensatory binding where complementarity of only 4 - 5 base pairs of the miRNA seed is compensated by extensive binding of the rest of the miRNA [3] [4] [40] [82]-[84] (Figure 3(B)). More recently, an alternative approach to finding miRNA targets utilizes a biochemical assay to isolate and sequence Argonaute-bound messenger transcripts, which has expanded our understanding of base-pairing rules and interestingly has shown that a large percentage of targets are bound in exon regions [44] [45] [84] [85]. In particular, a ligation-based method has been developed for directly associating miRNAs with their RNA targets [84]. Although the efficiency of this protocol is currently very low (only $2 \%$ of sequenced reads are ligated miRNA-RNA hybrid reads), this method holds exciting promise for uncovering miRNA target binding rules and improving microRNA-based RNAi technology.

A second major challenge is in considering the regulation of microRNA biogenesis. Once miRNAs are transcribed, the hairpin forms within a larger primary transcript. It has been demonstrated that sequences within the flanking 5' and 3' tails are required for proper Drosha processing [86]. Sequences in the 3' tail have been shown to contain miRNA binding sites, suggesting that the 3' tails may serve as a regulatory region akin to 3'UTRs for messenger RNAs [87] [88]. Furthermore, both the tail and loop regions contain binding sites for regulatory RNA binding proteins [89] [90]. Therefore, when expressing miRNA-based RNAi vectors outside of their endogenous context, potential regulation in these loop and tail regions must be considered. Even for the miRNA duplex, one must consider the potential production of miRNA isoforms (isomiRs) that differ in either the 5' or 3' end [91] [92], which may be a source of unexpected off-target effects. Since many facets of the microRNA biogenesis pathway are still poorly understood [38], there is currently still an element of trial-and-error in designing proper miRNA RNAi vectors.

\section{Conclusion}

Despite intensive research over the past decade, the field of microRNA biology is still in its infancy and many 
fundamental questions remain unanswered. There are still many gaps in our understanding of the molecular machinery involved in microRNA biogenesis, processing, targeting, and degradation. Nonetheless, microRNAs are naturally produced in almost all model systems, have the demonstrated ability to induce near-complete knockdown of target transcript and/or protein levels, and offer the versatility necessary to be used as vehicles for RNA interference in animals.

\section{Acknowledgements}

J.S.C. thanks V. Hurless for helpful discussions. This work was supported by National Science Foundation Grants IOS-0347937 and IOS-0951347 to R.W.Z.

\section{References}

[1] Lu, J., Getz, G., Miska, E.A., Alvarez-Saavedra, E., Lamb, J., et al. (2005) MicroRNA Expression Profiles Classify Human Cancers. Nature, 435, 834-838. http://dx.doi.org/10.1038/nature03702

[2] Calin, G.A. and Croce, C.M. (2006) MicroRNA-Cancer Connection: The Beginning of a New Tale. Cancer Research, 66, 7390-7394. http://dx.doi.org/10.1158/0008-5472.CAN-06-0800

[3] Bartel, D.P. (2009) MicroRNAs: Target Recognition and Regulatory Functions. Cell, 136, 215-233. http://dx.doi.org/10.1016/j.cell.2009.01.002

[4] Lee, R.C., Feinbaum, R.L. and Ambros, V. (1993) The C. elegans Heterochronic Gene Lin-4 Encodes Small RNAs with Antisense Complementarity to Lin-14. Cell, 75, 843-854. http://dx.doi.org/10.1016/0092-8674(93)90529-Y

[5] Wightman, B., Ha, I. and Ruvkun, G. (1993) Posttranscriptional Regulation of the Heterochronic Gene Lin-14 by Lin-4 Mediates Temporal Pattern Formation in C. elegans. Cell, 75, 855-862. http://dx.doi.org/10.1016/0092-8674(93)90530-4

[6] Ha, I., Wightman, B. and Ruvkun, G. (1996) A Bulged Lin-4/Lin-14 RNA Duplex Is Sufficient for Caenorhabditis elegans Lin-14 Temporal Gradient Formation. Genes \& Development, 10, 3041-3050. http://dx.doi.org/10.1101/gad.10.23.3041

[7] Moss, E.G., Lee, R.C. and Ambros, V. (1997) The Cold Shock Domain Protein LIN-28 Controls Developmental Timing in C. elegans and Is Regulated by the Lin-4 RNA. Cell, 88, 637-646. http://dx.doi.org/10.1016/S0092-8674(00)81906-6

[8] Olsen, P.H. and Ambros, V. (1999) The Lin-4 Regulatory RNA Controls Developmental Timing in Caenorhabditis elegans by Blocking LIN-14 Protein Synthesis after the Initiation of Translation. Developmental Biology, 216, 671-680. http://dx.doi.org/10.1006/dbio.1999.9523

[9] Reinhart, B.J., Slack, F.J., Basson, M., Pasquinelli, A.E., Bettinger, J.C., et al. (2000) The 21-Nucleotide Let-7 RNA Regulates Developmental Timing in Caenorhabditis elegans. Nature, 403, 901-906. http://dx.doi.org/10.1038/35002607

[10] Waterston, R. and Sulston, J. (1998) The Human Genome Project: Reaching the Finish Line. Science, 282, 53-54. http://dx.doi.org/10.1126/science.282.5386.53

[11] Adams, M.D., Celniker, S.E., Holt, R.A., Evans, C.A., Gocayne, J.D., et al. (2000) The Genome Sequence of Drosophila Melanogaster. Science, 287, 2185-2195. http://dx.doi.org/10.1126/science.287.5461.2185

[12] Venter, J.C., Adams, M.D., Myers, E.W., Li, P.W., Mural, R.J., et al. (2001) The Sequence of the Human Genome. Science, 291, 1304-1351. http://dx.doi.org/10.1126/science.1058040

[13] Chinwalla, A.T., Cook, L.L., Delehaunty, K.D., Fewell, G.A., Fulton, L.A., et al. (2002) Initial Sequencing and Comparative Analysis of the Mouse Genome. Nature, 420, 520-562. http://dx.doi.org/10.1038/nature01262

[14] Pasquinelli, A.E., Reinhart, B.J., Slack, F., Martindale, M.Q., Kuroda, M.I., et al. (2000) Conservation of the Sequence and Temporal Expression of Let-7 Heterochronic Regulatory RNA. Nature, 408, 86-89. http://dx.doi.org/10.1038/35040556

[15] Lau, N.C., Lim, L.P., Weinstein, E.G. and Bartel, D.P. (2001) An Abundant Class of Tiny RNAs with Probable Regulatory Roles in Caenorhabditis elegans. Science, 294, 858-862. http://dx.doi.org/10.1126/science.1065062

[16] Lagos-Quintana, M., Rauhut, R., Yalcin, A., Meyer, J., Lendeckel, W., et al. (2002) Identification of Tissue-Specific microRNAs from Mouse. Current Biology, 12, 735-739. http://dx.doi.org/10.1016/S0960-9822(02)00809-6

[17] Aravin, A.A., Lagos-Quintana, M., Yalcin, A., Zavolan, M., Marks, D., et al. (2003) The Small RNA Profile during Drosophila melanogaster Development. Developmental Cell, 5, 337-350. http://dx.doi.org/10.1016/S1534-5807(03)00228-4

[18] Grad, Y., Aach, J., Hayes, G.D., Reinhart, B.J., Church, G.M., et al. (2003) Computational and Experimental Identifi- 
cation of C. elegans microRNAs. Molecular Cell, 11, 1253-1263. http://dx.doi.org/10.1016/S1097-2765(03)00153-9

[19] Lagos-Quintana, M., Rauhut, R., Meyer, J., Borkhardt, A. and Tuschl, T. (2003) New microRNAs from Mouse and Human. RNA, 9, 175-179. http://dx.doi.org/10.1261/rna.2146903

[20] Lim, L.P., Lau, N.C., Weinstein, E.G., Abdelhakim, A., Yekta, S., et al. (2003) The microRNAs of Caenorhabditis elegans. Genes \& Development, 17, 991-1008. http://dx.doi.org/10.1101/gad.1074403

[21] Ambros, V. (2004) The Functions of Animal microRNAs. Nature, 431, 350-355. http://dx.doi.org/10.1038/nature02871

[22] Bartel, D.P. (2004) MicroRNAs: Genomics, Biogenesis, Mechanism, and Function. Cell, 116, 281-297. http://dx.doi.org/10.1016/S0092-8674(04)00045-5

[23] Bentwich, I., Avniel, A., Karov, Y., Aharonov, R., Gilad, S., et al. (2005) Identification of Hundreds of Conserved and Nonconserved Human microRNAs. Nature Genetics, 37, 766-770. http://dx.doi.org/10.1038/ng1590

[24] Chen, P.Y., Manninga, H., Slanchev, K., Chien, M., Russo, J.J., et al. (2005) The Developmental miRNA Profiles of Zebrafish as Determined by Small RNA Cloning. Genes \& Development, 19, 1288-1293. http://dx.doi.org/10.1101/gad.1310605

[25] Watanabe, T., Takeda, A., Mise, K., Okuno, T., Suzuki, T., et al. (2005) Stage-Specific Expression of microRNAs during Xenopus Development. FEBS Letters, 579, 318-324. http://dx.doi.org/10.1016/j.febslet.2004.11.067

[26] Ruby, J.G., Stark, A., Johnston, W.K., Kellis, M., Bartel, D.P., et al. (2007) Evolution, Biogenesis, Expression, and Target Predictions of a Substantially Expanded Set of Drosophila microRNAs. Genome Research, 17, 1850-1864. http://dx.doi.org/10.1101/gr.6597907

[27] Thatcher, E.J., Paydar, I., Anderson, K.K. and Patton, J.G. (2008) Regulation of Zebrafish Fin Regeneration by microRNAs. PNAS, 105, 18384-18389. http://dx.doi.org/10.1073/pnas.0803713105

[28] Glazov, E.A., Cottee, P.A., Barris, W.C., Moore, R.J., Dalrymple, B.P., et al. (2008) A microRNA Catalog of the Developing Chicken Embryo Identified by a Deep Sequencing Approach. Genome Research, 18, 957-964. http://dx.doi.org/10.1101/gr.074740.107

[29] He, P.-A., Nie, Z., Chen, J., Chen, J., Lv, Z., et al. (2008) Identification and Characteristics of microRNAs from Bombyx mori. BMC Genomics, 9, 248. http://dx.doi.org/10.1186/1471-2164-9-248

[30] Yu, X., Zhou, Q., Li, S.C., Luo, Q., Cai, Y., et al. (2008) The Silkworm (Bombyx mori) microRNAs and Their Expressions in Multiple Developmental Stages. PLoS One, 3, e2997. http://dx.doi.org/10.1371/journal.pone.0002997

[31] Chen, X., Li, Q., Wang, J., Guo, X., Jiang, X., et al. (2009) Identification and Characterization of Novel Amphioxus microRNAs by Solexa Sequencing. Genome Biology, 10, R78. http://dx.doi.org/10.1186/gb-2009-10-7-r78

[32] Shi, W., Hendrix, D., Levine, M. and Haley, B. (2009) A Distinct Class of Small RNAs Arises from Pre-miRNAProximal Regions in a Simple Chordate. Nature Structural \& Molecular Biology, 16, 183-189. http://dx.doi.org/10.1038/nsmb.1536

[33] Wheeler, B.M., Heimberg, A.M., Moy, V.N., Sperling, E.A., Holstein, T.W., et al. (2009) The Deep Evolution of Metazoan microRNAs. Evolution \& Development, 11, 50-68. http://dx.doi.org/10.1111/j.1525-142X.2008.00302.x

[34] Hendrix, D., Levine, M. and Shi, W. (2010) Method miRTRAP, a Computational Method for the Systematic Identification of miRNAs from High Throughput Sequencing Data. Genome Biology, 11, R39. http://dx.doi.org/10.1186/gb-2010-11-4-r39

[35] Keshavan, R., Virata, M., Keshavan, A. and Zeller, R.W. (2010) Computational Identification of Ciona intestinalis microRNAs. Zoological Science, 27, 162-170. http://dx.doi.org/10.2108/zsj.27.162

[36] Berezikov, E., Robine, N., Samsonova, A., Westholm, J.O., Naqvi, A., Hung, J.H., Okamura, K., Dai, Q., BortolamiolBecet, D., Martin, R., Zhao, Y.J., Zamore, P.D., Hannon, G.J., Marra, M.A., Weng, Z.P., Perrimon, N. and Lai, E.C. (2011) Deep Annotation of Drosophila Melanogaster microRNAs Yields Insights into Their Processing, Modification, and Emergence. Genome Research, 21, 203-215. http://dx.doi.org/10.1101/gr.116657.110

[37] Lai, E.C. (2003) microRNAs: Runts of the Genome Assert Themselves. Current Biology, 13, R925-R936. http://dx.doi.org/10.1016/j.cub.2003.11.017

[38] Du, T. and Zamore, P.D. (2005) microPrimer: The Biogenesis and Function of microRNA. Development, 132, 46454652. http://dx.doi.org/10.1242/dev.02070

[39] Kim, V.N., Han, J. and Siomi, M.C. (2009) Biogenesis of Small RNAs in Animals. Nature Reviews Molecular Cell Biology, 10, 126-139. http://dx.doi.org/10.1038/nrm2632

[40] Lai, E.C. (2004) Predicting and Validating microRNA Targets. Genome Biology, 5, 115. http://dx.doi.org/10.1186/gb-2004-5-9-115

[41] Aboobaker, A.A., Tomancak, P., Patel, N., Rubin, G.M. and Lai, E.C. (2005) Drosophila microRNAs Exhibit Diverse 
Spatial Expression Patterns during Embryonic Development. Proceedings of the National Academy of Sciences of the United States of America, 102, 18017-18022.

http://dx.doi.org/10.1073/pnas.0508823102

[42] Chen, J. and Zeller, R. (2009) Regulation of Gene Expression by the microRNA miR-124 in the Developing Nervous System of C. Intestinalis. ACSESS Proceedings AP0904, San Diego, 27 March 2009, 1-6.

[43] Chen, J.S., San Pedro, M. and Zeller, R.W. (2011) miR-124 Function during Ciona intestinalis Neuronal Development Includes Extensive Interaction with the Notch Signaling Pathway. Development, 138, 4943-4953. http://dx.doi.org/10.1242/dev.068049

[44] Chi, S.W., Zang, J.B., Mele, A. and Darnell, R.B. (2009) Argonaute HITS-CLIP Decodes microRNA-mRNA Interaction Maps. Nature, 460, 479-486.

[45] Zisoulis, D.G., Lovci, M.T., Wilbert, M.L., Hutt, K.R., Liang, T.Y., Pasquinelli, A.E. and Yeo, G.W. (2010) Comprehensive Discovery of Endogenous Argonaute Binding Sites in Caenorhabditis elegans. Nature Structural \& Molecular Biology, 17, 173-179. http://dx.doi.org/10.1038/nsmb.1745

[46] Krichevsky, A.M., King, K.S., Donahue, C.P., Khrapko, K. and Kosik, K.S. (2003) A microRNA Array Reveals Extensive Regulation of microRNAs during Brain Development. RNA, 9, 1274-1281. http://dx.doi.org/10.1261/rna.5980303

[47] Ruby, J.G., Jan, C., Player, C., Axtell, M.J., Lee, W., Nusbaum, C., Ge, H. and Bartel, D.P. (2006) Large-Scale Sequencing Reveals 21U-RNAs and Additional microRNAs and Endogenous siRNAs in C. elegans. Cell, 127, 11931207. http://dx.doi.org/10.1016/j.cell.2006.10.040

[48] Kozomara, A. and Griffiths-Jones, S. (2011) miRbase: Integrating microRNA Annotation and Deep-Sequencing Data. Nucleic Acids Research, 39, D152-D157. http://dx.doi.org/10.1093/nar/gkq1027

[49] Landgraf, P., Rusu, M., Sheridan, R., Sewer, A., Iovino, N., et al. (2007) A Mammalian microRNA Expression Atlas Based on Small RNA Library Sequencing. Cell, 129, 1401-1414. http://dx.doi.org/10.1016/j.cell.2007.04.040

[50] Hertel, J., Lindemeyer, M., Missal, K., Fried, C., Tanzer, A., Flamm, C., Hofacker, I.L., Stadler, P.F. and The Students of Bioinformatics Computer Labs 2004 and 2005 (2006) The Expansion of the Metazoan microRNA Repertoire. BMC Genomics, 7, 25. http://dx.doi.org/10.1186/1471-2164-7-25

[51] Okamura, K., Phillips, M.D., Tyler, D.M., Duan, H., Chou, Y.T. and La, E.C. (2008) The Regulatory Activity of microRNA* Species Has Substantial Influence on microRNA and 3’UTR Evolution. Nature Structural \& Molecular Biology, 15, 354-363. http://dx.doi.org/10.1038/nsmb.1409

[52] Yang, J.S., Phillips, M.D., Betel, D., Mu, P., Ventura, A., Siepel, A.C., Chen, K.C. and Lai, E.C. (2011) Widespread Regulatory Activity of Vertebrate microRNA* Species. RNA, 17, 312-326. http://dx.doi.org/10.1261/rna.2537911

[53] Fire, A., Xu, S., Montgomery, M.K., Kostas, S.A., Driver, S.E. and Mello, C.C. (1998) Potent and Specific Genetic Interference by Double-Stranded RNA in Caenorhabditis elegans. Nature, 391, 806-811. http://dx.doi.org/10.1038/35888

[54] Kim, D.H. and Rossi, J.J. (2007) Strategies for Silencing Human Disease Using RNA Interference. Nature Reviews Genetics, 8, 173-184. http://dx.doi.org/10.1038/nrg2006

[55] Elbashir, S.M., Harborth, J., Lendeckel, W., Yalcin, A., Weber, K. and Tuschl, T. (2001) Duplexes of 21-Nucleotide RNAs Mediate RNA Interference in Cultured Mammalian Cells. Nature, 411, 494-498. http://dx.doi.org/10.1038/35078107

[56] McFarland, T.J., Zhang, Y., Appukuttan, B. and Stout, J.T. (2004) Gene Therapy for Proliferative Ocular Diseases. Expert Opinion on Biological Therapy, 4, 1053-1058. http://dx.doi.org/10.1517/14712598.4.7.1053

[57] Bitko, V., Musiyenko, A., Shulyayeva, O. and Barik, S. (2004) Inhibition of Respiratory Viruses by Nasally Administered siRNA. Nature Medicine, 11, 50-55. http://dx.doi.org/10.1038/nm1164

[58] Rossi, J.J. (2006) RNAi as a Treatment for HIV-1 Infection. Biotechniques, 40, S25-S29. http://dx.doi.org/10.2144/000112167

[59] Dykxhoorn, D.M. and Lieberman, J. (2006) Silencing Viral Infection. PLoS Medicine, 3, e242. http://dx.doi.org/10.1371/journal.pmed.0030242

[60] Raoul, C., Barker, S. and Aebischer, P. (2005) Viral-Based Modelling and Correction of Neurodegenerative Diseases by RNA Interference. Gene Therapy, 13, 487-495. http://dx.doi.org/10.1038/sj.gt.3302690

[61] Pai, S., Lin, Y., Macaes, B., Meneshian, A., Hung, C. and Wu, T.C. (2005) Prospects of RNA Interference Therapy for Cancer. Gene Therapy, 13, 464-477. http://dx.doi.org/10.1038/sj.gt.3302694

[62] Stegmeier, F., Hu, G., Rickles, R.J., Hannon, G.J. and Elledge, S.J. (2005) A Lentiviral microRNA-Based System for Single-Copy Polymerase II-Regulated RNA Interference in Mammalian Cells. Proceedings of the National Academy of Sciences of the United States of America, 102, 13212-13217. http://dx.doi.org/10.1073/pnas.0506306102 
[63] Dykxhoorn, D.M., Novina, C.D. and Sharp, P.A. (2003) Killing the Messenger: Short RNAs that Silence Gene Expression. Nature Reviews Molecular Cell Biology, 4, 457-467. http://dx.doi.org/10.1038/nrm1129

[64] Dickins, R.A., Hemann, M.T., Zilfou, J.T., Simpson, D.R., Ibarra, I., Hannon, G.J. and Lowe, S.W. (2005) Probing Tumor Phenotypes Using Stable and Regulated Synthetic microRNA Precursors. Nature Genetics, 37, 1289-1295.

[65] Silva, J.M., Li, M.Z., Chang, K., Ge, W., Golding, M.C., et al. (2005) Second-Generation shRNA Libraries Covering the Mouse and Human Genomes. Nature Genetics, 37, 1281-1288.

[66] Sarnova, L., Malik, R., Sedlacek, R. and Svoboda, P. (2010) Shortcomings of Short Hairpin RNA-Based Transgenic RNA Interference in Mouse Oocytes. Journal of Negative Results in Biomedicine, 9, 8.

[67] Chung, K.H., Hart, C.C., Al-Bassam, S., Avery, A., Taylor, J., Patel, P.D., Vojtek, A.B. and Turner, D.L. (2006) Polycistronic RNA Polymerase II Expression Vectors for RNA Interference Based on Bic/miR-155. Nucleic Acids Research, 34, e53. http://dx.doi.org/10.1093/nar/gkl143

[68] Zeng, Y., Wagner, E.J. and Cullen, B.R. (2002) Both Natural and Designed Micro RNAs Can Inhibit the Expression of Cognate mRNAs when Expressed in Human Cells. Molecular Cell, 9, 1327-1333. http://dx.doi.org/10.1016/S1097-2765(02)00541-5

[69] Du, G., Yonekubo, J., Zeng, Y., Osisami, M. and Frohman, M.A. (2006) Design of Expression Vectors for RNA Interference Based on miRNAs and RNA Splicing. FEBS Journal, 273, 5421-5427. http://dx.doi.org/10.1111/j.1742-4658.2006.05534.x

[70] De Veer, M.J., Sledz, C.A. and Williams, B.R. (2005) Detection of Foreign RNA: Implications for RNAi. Immunology and Cell Biology, 83, 224-228. http://dx.doi.org/10.1111/j.1440-1711.2005.01337.x

[71] Ossowski, S., Schwab, R. and Weigel, D. (2008) Gene Silencing in Plants Using Artificial microRNAs and Other Small RNAs. The Plant Journal, 53, 674-690. http://dx.doi.org/10.1111/j.1365-313X.2007.03328.x

[72] Niu, Q.W., Lin, S.S., Reyes, J.L., Chen, K.C., Wu, H.W., Yeh, S.D. and Chua, N.H. (2006) Expression of Artificial microRNAs in Transgenic Arabidopsis Thaliana Confers Virus Resistance. Nature Biotechnology, 24, 1420-1428. http://dx.doi.org/10.1038/nbt1255

[73] Schwab, R., Ossowski, S., Riester, M., Warthmann, N. and Weigel, D. (2006) Highly Specific Gene Silencing by Artificial microRNAs in Arabidopsis. The Plant Cell Online, 18, 1121-1133. http://dx.doi.org/10.1105/tpc.105.039834

[74] Zhang, X., Li, H., Zhang, J., Zhang, C., Gong, P., Ziaf, K., Xiao, F.M. and Ye, Z.B. (2011) Expression of Artificial microRNAs in Tomato Confers Efficient and Stable Virus Resistance in a Cell-Autonomous Manner. Transgenic Research, 20, 569-581. http://dx.doi.org/10.1007/s11248-010-9440-3

[75] Molnar, A., Bassett, A., Thuenemann, E., Schwach, F., Karkare, S., Ossowski, S., Weigel, D. and Baulcombe, D. (2009) Highly Specific Gene Silencing by Artificial microRNAs in the Unicellular Alga Chlamydomonas reinhardtii. The Plant Journal, 58, 165-174. http://dx.doi.org/10.1111/j.1365-313X.2008.03767.x

[76] Zhao, T., Wang, W., Bai, X. and Qi, Y. (2009) Gene Silencing by Artificial microRNAs in Chlamydomonas. The Plant Journal, 58, 157-164. http://dx.doi.org/10.1111/j.1365-313X.2008.03758.x

[77] Grimson, A., Farh, K.K.H., Johnston, W.K., Garrett-Engele, P., Lim, L.P. and Bartel, D.P. (2007) microRNA Targeting Specificity in Mammals: Determinants beyond Seed Pairing. Molecular Cell, 27, 91-105. http://dx.doi.org/10.1016/j.molcel.2007.06.017

[78] Joyce Tang, W., Chen, J.S. and Zeller, R.W. (2013) Transcriptional Regulation of the Peripheral Nervous System in Ciona intestinalis. Developmental Biology, 378, 183-193. http://dx.doi.org/10.1016/j.ydbio.2013.03.016

[79] Lewis, B.P., Burge, C.B. and Bartel, D.P. (2005) Conserved Seed Pairing, Often Flanked by Adenosines, Indicates that Thousands of Human Genes Are microRNA Targets. Cell, 120, 15-20. http://dx.doi.org/10.1016/j.cell.2004.12.035

[80] Clark, A.M., Goldstein, L.D., Tevlin, M., Tavare, S., Shaham, S. and Miska, E.A. (2010) The microRNA miR-124 Controls Gene Expression in the Sensory Nervous System of Caenorhabditis elegans. Nucleic Acids Research, 38, 3780-3793. http://dx.doi.org/10.1093/nar/gkq083

[81] Kertesz, M., Iovino, N., Unnerstall, U., Gaul, U. and Segal, E. (2007) The Role of Site Accessibility in microRNA Target Recognition. Nature Genetics, 39, 1278-1284. http://dx.doi.org/10.1038/ng2135

[82] Brennecke, J., Stark, A., Russell, R.B. and Cohen, S.M. (2005) Principles of microRNA-Target Recognition. PLoS Biology, 3, Article ID: e85. http://dx.doi.org/10.1371/journal.pbio.0030085

[83] Shin, C., Nam, J.W., Farh, K.K.H., Chiang, H.R., Shkumatava, A. and Bartel, D.P. (2010) Expanding the microRNA Targeting Code: Functional Sites with Centered Pairing. Molecular Cell, 38, 789-802. http://dx.doi.org/10.1016/j.molcel.2010.06.005

[84] Helwak, A., Kudla, G., Dudnakova, T. and Tollervey, D. (2013) Mapping the Human miRNA Interactome by CLASH Reveals Frequent Noncanonical Binding. Cell, 153, 654-665. http://dx.doi.org/10.1016/j.cell.2013.03.043

[85] Hafner, M., Landthaler, M., Burger, L., Khorshid, M., Hausser, J., et al. (2010) Transcriptomewide Identification of 
RNA-Binding Protein and microRNA Target Sites by PAR-CLIP. Cell, 141, 129-141. http://dx.doi.org/10.1016/j.cell.2010.03.009

[86] Zeng, Y. and Cullen, B.R. (2005) Efficient Processing of Primary microRNA Hairpins by Drosha Requires Flanking Nonstructured RNA Sequences. Journal of Biological Chemistry, 280, 27595-27603. http://dx.doi.org/10.1074/jbc.M504714200

[87] Tang, R., Li, L., Zhu, D., Hou, D., Cao, T., Gu, H.W., Zhang, J., Chen, J.Y., Zhang, C.Y. and Zen, K. (2011) Mouse miRNA-709 Directly Regulates miRNA-15a/16-1 Biogenesis at the Posttranscriptional Level in the Nucleus: Evidence for a microRNA Hierarchy System. Cell Research, 22, 504-515. http://dx.doi.org/10.1038/cr.2011.137

[88] Zisoulis, D.G., Kai, Z.S., Chang, R.K. and Pasquinelli, A.E. (2012) Autoregulation of microRNA Biogenesis by let-7 and Argonaute. Nature, 486, 541-544. http://dx.doi.org/10.1038/nature11134

[89] Wilbert, M.L., Huelga, S.C., Kapeli, K., Stark, T.J., Liang, T.Y., et al. (2012) LIN28 Binds Messenger RNAs at GGAGA Motifs and Regulates Splicing Factor Abundance. Molecular Cell, 48, 195-206. http://dx.doi.org/10.1016/j.molcel.2012.08.004

[90] Van Wynsberghe, P.M., Kai, Z.S., Massirer, K.B., Burton, V.H., Yeo, G.W. and Pasquinelli, A.E. (2011) LIN-28 Co-Transcriptionally Binds Primary let-7 to Regulate miRNA Maturation in Caenorhabditis elegans. Nature Structural \& Molecular Biology, 18, 302-308. http://dx.doi.org/10.1038/nsmb.1986

[91] Neilsen, C.T., Goodall, G.J. and Bracken, C.P. (2012) IsomiRs-the Overlooked Repertoire in the Dynamic microRNAome. Trends in Genetics, 28, 544-549. http://dx.doi.org/10.1016/j.tig.2012.07.005

[92] Zhou, H., Arcila, M.L., Li, Z., Lee, E.J., Henzler, C., Liu, J.Y., Rana, T.M. and Kosik, K.S. (2012) Deep Annotation of Mouse iso-miR and iso-moR Variation. Nucleic Acids Research, 40, 5864-5875. http://dx.doi.org/10.1093/nar/gks247 